\title{
The Relationship Between Preschool Children's Social Competence Skills and Their Ability To Communicate With Their Mothers
}

\author{
Hale Dere Çiftçi \\ Department of Child Development, Faculty of Health Sciences, University of Istinye, Istanbul, \\ Turkey. \\ ORCID: 0000-0003-4524-4685
}

Remziye Ceylan

Department of Preschool Education, Faculty of Education, Yildiz Technical University, Istanbul, Turkey.

ORCID: 0000-0003-3227-7189

\author{
Feride Gök Çolak * \\ Department of Preschool Education, Faculty of Education, Yildiz Technical University, \\ Istanbul, Turkey. \\ ORCID: 0000-0001-5196-9178
}

Article history

Received:

20.09.2020

Received in revised form: 16.12.2020

Accepted:

30.12.2020

Key words:

parent relations,

inward and outward oriented behaviors,

preschool child and social competence.
The aim of this study was to determine the relationship between four to five year old children's social competence levels and their ability to communicate with their mothers. Social competence has an important role in developing positive relationships in children's lives. One of the most important factors in the development of social competence in children is the communication they have with their mothers. In the study, one of the general survey models, "relational survey model" was used. The study group consisted of 323 children attending public kindergartens in Istanbul. General Information Form, Social Competence and Behavior Assessment Scale and Parent-Child Communication Assessment Tool were used as data collection tools. In the analysis of the data, descriptive statistics were calculated via examining the data distribution. In order to determine the relationships between preschool children's mothers' communication and social competence, Pearson correlation coefficient was calculated. At the end of the study, it was observed that children's social competence average was high, and the mean of inward and outward oriented problems were close and low. Besides, there was a negative and high-level correlation between total social competence scores and inward oriented and outward oriented problems. Considering mothers' communication with their children, there was a positive and high-level relationship between the empathy and speech dimensions. While there was no significant relationship between the total scores of children's social competence levels and their relationship with their

\footnotetext{
*Correspondency: fgok@yildiz.edu.tr
} 
mothers, some significant relationships were determined regarding subdimensions. These results of the present study show that mothers' communication skills such as empathy, speaking, listening and conveying messages are effective in increasing children's social competence skills and reduce behavioral problems.

\section{Introduction}

Early childhood is an important period for children to acquire basic social skills that enable them to become socially competent individuals. Many basic social-emotional skills and traits include the following features: the ability to express and manage emotions, to move away from egocentrism, to understand events and phenomena from someone else's perspective, empathy, self-confidence, and to develop and support relationships with others. Social and emotional competence is also important for children's success in their environment and in later life (Darling-Churchill \& Lippman, 2016; Lim, Rodger \& Brown, 2010).

Social and emotional competence measure the ability to understand, maintain, manage, and express social and emotional aspects of life (Cohen, 2001). Social competence is associated with children's well-being, self-awareness, self-control, communication, and decision-making skills. These skills support children's adaptation to the environment they live in, increase their capacity to develop positive relationships with adults and peers, focus on challenging tasks, strive them to accomplish these tasks and also support them in using emotions during communication (Ashdown \& Bernard, 2012; Dere Ciftci, 2018).

In order for the child to develop healthfully, to become a healthy individual in the society and to develop social skills, the close relationship s/he has established with her/his parents is important as they are the closest individuals to the child (Akgun \& Yesilyaprak, 2010). The quality of the parent-child relationship, the development of the child's social skills along with lifelong mental health, have a significant impact on social competence and educational attainment (Simkiss et al. 2013). When compared with their peers, it is seen that preschool children's social competence increases as they interact with other children. In other words, these children are able to resolve interpersonal conflicts well, and become more adequate to establish a positive interaction with others, to initiate and maintain cooperation (Kennedy, 2018). Children's interactions with their parents at an early age form their oral and physical communication patterns with their peers in the future (Mei-Ju, Chen-Hsin \& Pin-Chen, 2014).

Preschool children's relationships with their parents and parents' attitudes towards their children (eg, Halpenny, Nixon \& Watson, 2010; Kordi \& Baharudin, 2010) affect their social development and competencies positively or negatively (Diener \& Kim, 2004; Patterson \& Sanson, 1999). The positive interaction of the parent and other individuals in the family with the child provides the necessary environment for the child to develop a sense of trust and to get accepted socially. Parents are the most important models that strongly affect the emotional expressions and social skills of the child in their social and emotional development (Dereli \& Dereli, 2017). Children who are exposed to negative behaviors by their parents have inadequacies in their social skills and as a result of these deficiencies, behavioral problems emerge (Wood, Emerson \& Cowan, 2004). Behavioral problems are generally classified as internalizing (e.g. Morgan, Izard \& Hyde, 2013) and externalizing behavioral problems (Yasar Ekici, 2014; Yoleri, 2014). Behaviors such as peer rejection (e.g. Smith, Simon \& Bramlett, 2009) and delinquency (e.g. Hong, Huang, Golden, Patton \& Washington, 2014) can be turned into outward-oriented behaviors. In the academic field, children who exhibit early behavioral problems may have difficulty in learning activities and participation in all 
general academic studies carried in the classroom (Aunola \& Nurmi, 2005; McWayne \& Cheung, 2009). In the present study, two sub-headings were taken into consideration. These are social competence and communication with parents.

\section{Social Competence}

Social competence is described as a structure formed with social harmony, social performance, and social skills (Bayindir, Guven, Sezer, Aksin-Yavuz \& Yilmaz, 2017). Social competence skills include child's appropriate reaction regarding the situation $\mathrm{s} / \mathrm{he}$ is in, her/his behaviors regarding their peers' rules and behaviors of healthy communication (Aral \& Kadan, 2018).

Social competence skills that have started to develop in preschool period increase with age and children begin to interact effectively with others. At the age of three to four, children begin to establish emotional ties with friends outside the family and understand the differences between being socially accepted and behaviors that are unacceptable. He can handle difficult tasks without getting angry and focus his attention on these tasks for a longer period. At the age of five, he plays various games to test his skills, enjoys being with other children, wants to be with them, can deal with small groups and he is interested in home activities. In addition, he does not have any problems with the skills of imitating various roles and models, waiting for his turn, sharing, and helping while playing. Gaining social competence affect children's academic life and social situations positively in the future (Halle \& Darling-Churchill, 2016; Humphrey, 2003; Thomson \& Carlson, 2017).

Social competence is important for the success of children in school as well as in other settings and periods of life. Children with advanced social competence skills have high selfconfidence and can interact well with people around them, they improve their social relationships, listen to instructions carefully and are kind. In addition, these children enjoy having conversations with their peers, can solve interpersonal problems without struggling, participate in group games, express their feelings and thoughts more easily, understand the feelings of other individuals without any difficulty, tend to cooperate and enjoy helping and are able to regulate emotional reactions during frustrating experiences (Darling-Churchill \& Lippman, 2016; Joseph \& Strain, 2003).

\section{Children's Social Competence Levels and Their Parents' Communication with Them}

The development of children's social competence skills starts with the relationship they establish with their parents and it continues with the communication they have with their siblings, peers, and other adults. Parents' warm relationships with their children, the compassionate and constructive interactions they form, their affection, the safe environment they provide along with positive verbal feedback are all important in terms of teaching them the rules that they must follow and their social acceptance (Deveci, 2011; Gander \& Gardiner, 2010; Ozyurek, Begde \& Yavuz, 2014). The positive parent-child relationship established during this period also affects child's social position positively in the following years (Scaramella \& Leve, 2004). In addition, effective communication with child helps him acquire the basic skills and behaviors necessary for interacting with peers and other individuals around him and ensures high self-esteem (e.g. Davis-Kean \& Sandler, 2001; Anme et.al., 2010).

Parents' focusing on the problem in their communication with their children, encouraging their children to express their feelings, sensitivity to their children, and talking with their 
children about their feelings are supportive reactions and behaviors and affect parents' communication with their children positively. On the other hand, parents' negative communication and non-supportive reactions such as strict parental behavior, punishment or stress in parents affect their communication with their children negatively. Studies examining the effects of mothers on their children's socialization have found a positive relationship between mothers' emotional supportive reactions and their children's social competence skills (Bayindir, Guven, Sezer, Aksin-Yavuz \& Yilmaz, 2017; Ozkan \& Aksoy, 2017). Various perspectives emphasized that children's social competence skills are based on their relationship with their fathers. Attachment theorists have focused on the quality of the emotional relationship between father and child. According to this view, the positive relationship established between father and child develops a reliable and supportive parent model and enables the child to approach other people with positive attitudes and expectations in the future. However, the negative relationship established with the child cause them to evaluate the models of the social world as unreliable and reduces their ability to become competent. For instance, the close relationship in father-child relationships, such as secure attachment, warmth, and positive relationship, would increase children's self-regulation abilities, help them show positive behaviors in their relationship with their peers, and increase the acceptance and popularity of peers in early childhood. Social-cognitive theorists have argued that fathers can influence their children's social competence skills through modeling. Research on this issue supported the idea that close father-child relationships contribute to the prediction of children's social competence skills (Zhang, 2013).

Emotional and behavioral problems have been the focus of many studies on early childhood recently (Alink et al., 2006). One of the reasons for this issue is the lack of early social competence skills (Ladd, 2000). It is stated that children with high social competence level do not have difficulty in adapting to the family and school environment, while children with low social competence or poor social competence skills do not have sufficient academic performance and have internalized and externalized behavioral problems (Burt, Obradovic, Long \& Masten, 2008; Parker, Rubin, Erath, Wojslawowiczx \& Buskirk, 2006; WebsterStratton \& Taylor, 2001).

\section{Study Questions}

When the relevant literature is examined, it is observed that there are many studies conducted on social competence (Anthony et al., 2005; Chen \& French, 2008; Cohn, 1990; Durmusoglu-Saltali \& Arslan, 2012; Gresham \& Reschly, 1987; Kilic, Kumandas \& Calik Var, 2016; LaFreniere \& et al., 2002; Ural, Guven, Sezer, Azkeskin \& Yilmaz, 2015; Varley $\&$ et al., 2019). In these studies the study groups vary. It is seen that there are three different study groups which are formed with normally developing children (Hygen et al., 2019), children who are inadequate in terms of social competence and the third study group is formed with children having special needs (Varley et al., 2019; Yavuz, Selcuk \& Korkmaz, 2017). This situation differentiates the focus of the studies. Social competence and parental attitudes (Gulay-Ogelman \& Topaloglu, 2014); attachment styles of children (Ural, Guven, Sezer, Azkeskin \& Yilmaz, 2015), play skills (Kocyigit, Yilmaz \& Sezer, 2015), parental selfefficacy, parenting discipline methods (Kilic, Kumveren \& Calik-Var, 2016) and social problem-solving skills (Yarali \& Ozkan, 2016) have been the focus of these studies. However, among the available sources, there are no studies examining the relationship between mothers' communication with their children and children's social competence. For this reason, the aim of this study was to examine the relationship between mothers' communication with their 4-5-year-old preschool children and their social competence levels. 
In this context, it is thought that it will contribute to the literature. In the study, answers to the following questions were sought:

Four- and five-year-old children

(1) Does the children's communication with their mothers differ according to their mothers`age and education level?

(2) Does the social competence levels of the children differ according to children's age, gender and number of siblings?

(3) What is the level of children's social competence?

(4) What is the level of communication between mothers and their children?

(5) Is there a relationship between children's social competence levels and mothers' communication with their children?

\section{Method}

\section{Research Design}

The research is in relational survey model which is one of the general screening models. Relational survey model, which is also called correlational model, is used in studies that examine the relationship between two or more variables without interfering with these variables (Buyukozturk et al., 2016).

\section{Study Group}

The study group of the study consisted of 4-5-year-old kindergartners that are attending schools affiliated to the Ministry of National Education in Istanbul during the 20182019 academic year. For this purpose, a total of 900 forms were replicated and distributed to these institutions. Some parents and schools refused to fill out the forms as there were items in the questionnaire that aimed to determine children's behavior problems. In the study, due to time and workforce limitations, convenience sampling method was preferred in the determination of the study sample. 334 children's mothers participated in the study. However, 11 forms were not included in the data analysis as some of the items were not answered. As a result, 323 children and their mothers participated in the study.

The frequency and percentage values for the distribution of children and parents and some of their demographic information are given in Tables 1 and 2.

Table 1. The distribution of parents' demographic information $(\mathrm{N}=323)$

\begin{tabular}{|c|c|c|c|c|c|}
\hline \multirow{2}{*}{ Parents } & & \multicolumn{2}{|c|}{ Mother } & \multicolumn{2}{|c|}{ Father } \\
\hline & & $\mathrm{f}$ & $\%$ & $\mathrm{f}$ & $\%$ \\
\hline \multirow{4}{*}{ Age } & Below 30 & 75 & 23,2 & 36 & 11,1 \\
\hline & Between 31-40 & 204 & 63,2 & 209 & 64,7 \\
\hline & Above 40 & 44 & 13,6 & 78 & 24,1 \\
\hline & Total & 323 & 100,0 & 323 & 100,0 \\
\hline \multirow{4}{*}{$\begin{array}{l}\text { Educational } \\
\text { Status }\end{array}$} & Secondary school and below & 90 & 27,9 & 80 & 24,8 \\
\hline & High school & 112 & 34,7 & 126 & 39,0 \\
\hline & University and above & 121 & 37,5 & 117 & 36,2 \\
\hline & Total & 323 & 100,0 & 323 & 100,0 \\
\hline \multirow[t]{2}{*}{ Profession } & Housewife & 199 & 61,6 & - & - \\
\hline & Worker & 19 & 5,8 & 83 & 25,7 \\
\hline
\end{tabular}




\begin{tabular}{lllll}
\hline Officer & 18 & 5,5 & 35 & 10,8 \\
Self-employed & 27 & 8,3 & 92 & 28,5 \\
White-collar (architect, instructor etc.) & 3 & 0,9 & 6 & 1,9 \\
Other (bank employee, medical & 57 & 17,6 & 107 & 33,1 \\
personnel, accountant, unemployed, & & & \\
salesperson, contractor) & 323 & 100,0 & 323 & 100,0 \\
\hline Total & 323
\end{tabular}

When the age of the parents was examined in Table 1, it was found that $63.2 \%$ of mothers (n $=204)$ and $64.7 \%$ of fathers $(f=209)$ were mostly between the ages of 31-40. When parents' educational status is examined, it is noteworthy that $37.5 \%$ of the mothers $(n=121)$ were mostly university graduates or had a master's degree, whereas $39.0 \%$ of the fathers $(n=126)$ were mostly high school graduates. When parents' professions were examined, it was found that $61.6 \%$ of the mothers $(n=199)$ were mostly housewives, while $28.5 \%$ of the fathers $(n=$ $92)$ were mostly self-employed and $25.7 \%$ of them $(n=83)$ were workers.

Table 2. The distribution of children's demographic information $(\mathrm{N}=323)$

\begin{tabular}{|c|c|c|c|}
\hline \multicolumn{2}{|l|}{ Children } & $\mathrm{f}$ & $\%$ \\
\hline \multirow[t]{3}{*}{ Age } & 4 & 143 & 44,3 \\
\hline & 5 & 180 & 55,7 \\
\hline & Total & 323 & 100,0 \\
\hline \multirow[t]{3}{*}{ Gender } & Girl & 152 & 47,1 \\
\hline & Boy & 171 & 52,9 \\
\hline & Total & 323 & 100,0 \\
\hline Number of & Single child & 80 & 24,8 \\
\hline \multirow[t]{3}{*}{ Siblings } & 1 sibling & 184 & 57,0 \\
\hline & 2 siblings or more & 59 & 18,3 \\
\hline & Total & 323 & 100,0 \\
\hline \multirow[t]{4}{*}{ Birth Order } & First & 166 & 51,4 \\
\hline & Second & 125 & 38,7 \\
\hline & Third or subsequent & 32 & 9,9 \\
\hline & Total & 323 & 100,0 \\
\hline
\end{tabular}

According to Table 2, it is seen that $44.3 \%$ of the children $(n=143)$ participating in the study were 4 -year-olds and $55.7 \%$ of them were 5 year-olds $(n=180) .47 .1 \%$ of the children $(n=$ 152) were girls and $52.9 \%$ of them $(n=171)$ were boys. $24.8 \%$ of the children $(n=80)$ were the only child in the family, $57.0 \%$ of them $(n=184)$ had one sibling and $18.3 \%$ of them $(n=$ 59) had 2 or more siblings. $51.4 \%$ of the children $(n=166)$ were born as the first child of the family, $38.7 \%$ of them $(n=125)$ were born as the second child and $9.9 \%$ of them $(n=32)$ were born as the third or subsequent.

\section{Measurement Tools}

General Information Form, Social Competence and Behavior Assessment Scale (Preschool Print) and Parent-Child Communication Assessment Tool (PCCAT) were used as data collection tools.

\section{a. General Information Form}

The General Information Form, which consists of questions developed by the researchers to determine some information about children (such as age, gender, number of siblings, birth order, school attendance) and their parents (such as marital status, education status, profession, and income) was used. 


\section{b. Social Competence and Behavior Assessment Scale (Preschool Print)}

The Social Competence and Behavior Assessment Scale (Preschool Print) was developed by LaFreniere and Dumas (1996) for 30-76 months-old children. The validity and reliability studies were conducted with sample groups in the United States (USA) and Canada. Psychometric features of the scale have been examined in many countries Brazil, China, Japan, Russia, Austria and Italy (Corapci Aksan, Arslan-Yalcin \& Yagmurlu, 2010). In the original form and in the adaptation studies carried in different countries, the internal consistency coefficients of the subscales were found to be .80 and above. The scale was adapted to Turkish for the first time by Corapci, Aksan, Arslan-Yalcin and Yagmurlu (2010). Later, it was developed by Uysal and Akman (2016) and adapted to Turkish again. The original form of the scale consists of 80 items of six Likert type and three dimensions (internal orientation problems, external orientation problems and social competence). Since the items in the internal orientation problem and external oriented problem sub-dimension of the scale were negative, it was stated that the items in these two dimensions should be recodded in the total score calculation.

In the process of adapting the Social Competence and Behavior Assessment Scale (SCBAS) into Turkish, first the translation of the scale was completed, and then expert opinions were obtained. Afterwards, the scale was applied to 457 four to six-year-old preschoolers. In order to determine the construct validity of the scale, confirmatory factor analysis was calculated, and it was determined that the construct validity of the scale was achieved according to the model-data fit coefficients $(\mathrm{RMSEA}=0.09 ; \mathrm{NFI}=0.92 ; \mathrm{NNFI}=0.94 ; \mathrm{CFI}=0.94)$.

The Cronbach Alpha coefficient of the scale has a good internal consistency ranging from 0.80 to 0.89 . The Cronbach Alpha coefficient calculated for each sub-dimension was found to be .88 for internal oriented problems and .86 for external oriented problems, and .94 for social competence. The reliability and validity studies conducted show that the scale is a convenient and easy-to-measure instrument that can be used to evaluate social competence and behavior.

\section{c. Parent-Child Communication Assessment Tool (PCCAT)}

Parent-Child Communication Assessment Tool (PCCAT) was developed by Arabac1 (2011) to evaluate the communication between parents and their 48-72 months-old children. The scale consists of 37 items in five-likert type and five sub-dimensions (speaking, listening, message, nonverbal communication, and empathy).

During the development process, the scale was applied to the parents of 206 48-72 monthsold preschoolers. Exploratory and confirmatory factor analyzes were calculated in accordance with the responses obtained from the parents. As a result of exploratory factor analysis carried out separately for each dimension, it was found that all items had a significant explanatory value in the dimension to which they belong, and the items explained the total variance in the dimensions between $30.18 \%$ and $39.75 \%$. As a result of the confirmatory factor analysis, $t-$ values of the items in the dimensions were significant and the model-data fit values calculated for each dimension were found satisfactory.

The internal consistency coefficient of the speech sub-dimension was found as $(\alpha) .67$, the internal consistency coefficient of the listening sub-dimension was $(\alpha) .70$, the internal consistency coefficient of the message sub-dimension was $(\alpha) .60$, the internal consistency coefficient of the non-verbal communication sub-dimension was $(\alpha) .56$ and the internal consistency coefficient of the empathy sub-dimension was $(\alpha) .73$. When the test-retest 
reliability results were examined; test-retest correlations were .93 for speech sub-dimension, .96 for listening sub-dimension, .98 for message sub-dimension, .95 for nonverbal communication sub-dimension, and .96 for empathy sub-dimension. Accordingly, the relationship between the two application results was found to be significant ( $\mathrm{p}<0.05$ ). According to the analyzes, the scale was accepted as a valid and reliable instrument (Arabaci \& Omeroglu, 2013).

The high scores obtained from the sub-dimensions of the Parent-Child Communication Assessment Tool (PCCAT) indicate that the parents have positive and effective communication with their children. On the other hand, low communication scores obtained from the sub-dimensions of the scale indicate that there are disruptive aspects in the communication of parents with their child (Arabaci \& Omeroglu, 2013).

\section{Procedures}

Before conducting the study, the ethics committee approval was obtained on the 14th September 2018 from the ethics committee of a public university in Istanbul. After obtaining ethical approval, official permission was obtained from the relevant National Education Directorate. Then, the school principals were informed about the purpose of the research and how to implement it. "Social Competence and Behavior Assessment Scale (Preschool Print) Scale" was applied to preschool teachers while "General Information Form" and "ParentChild Communication Assessment Tool (PCCAT) were applied to children's parents. Applying the Social Competence and Behavior Assessment Scale (Preschool Print) takes approximately 15 minutes for each child. The data within the scope of the research was collected as paper-and-pencil-data. Then, these data were entered into SPSS program and digitized.

\section{Data Analysis}

After transferring the data obtained in the study to SPSS 23.0 program, firstly the missing and incorrect data were examined. After completing the data editing process, the total scores were calculated on the basis of sub-dimensions and the distribution patterns of the scores in the dimensions were examined. In this direction, skewness and kurtosis coefficients were calculated and histogram graphs were created. The calculated skewness and kurtosis coefficients are shown in Table 3.

Table 3. Skewness and Kurtosis Coefficients results $(\mathrm{N}=323)$

\begin{tabular}{lllllll}
\hline Scale & Sub-dimensions & $\mathrm{N}$ & Skewness & SE & Kurtosis & SE \\
\hline \multirow{3}{*}{$\begin{array}{l}\text { Parent-child } \\
\text { communication }\end{array}$} & Speaking & 323 & $-0,391$ & 0,136 & 2,063 & 0,271 \\
& Listening & 323 & $-1,096$ & 0,136 & 2,112 & 0,271 \\
& Message & 323 & $-0,378$ & 0,136 & $-0,250$ & 0,271 \\
& Nonverbal communication & 323 & $-0,526$ & 0,136 & 1,924 & 0,271 \\
& Empathy & 323 & $-0,905$ & 0,136 & 2,608 & 0,271 \\
& Total & 323 & $-1,314$ & 0,136 & 4,928 & 0,271 \\
\hline \multirow{5}{*}{ Social competence } & Social competence & 323 & $-0,206$ & 0,136 & $-0,568$ & 0,271 \\
& Inward-oriented problems & 323 & 0,435 & 0,136 & $-0,301$ & 0,271 \\
& External oriented problems & 323 & 0,787 & 0,136 & 0,577 & 0,271 \\
& Total social competence & 323 & $-0,030$ & 0,136 & $-0,779$ & 0,271 \\
\hline
\end{tabular}

Büyüköztürk (2016) states that the skewness and kurtosis coefficients of the scores are within \pm 1 , indicating that the data are normally distributed and that there is no excessive deviation from the normal distribution. When the information in Table 3 is examined, it is seen that the 
social competence scores of preschool children show normal distribution, and their communication scores show nonnormal distribution. In addition, the histogram graphs generated show normal and nonnormal distribution of the data. Graphs for total scores are shown in Figure 1 as an example.

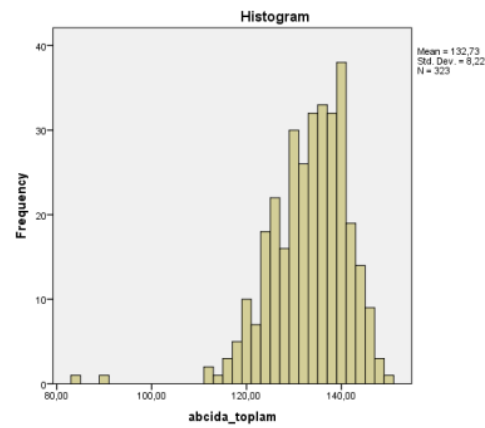

The distribution of parent-child communication scores

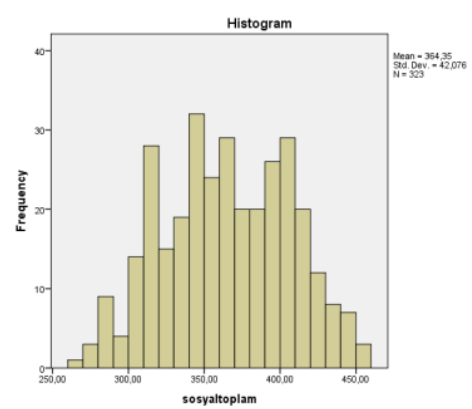

Distribution of social competence

Figure 1. Histogram graphs

As shown in Figure 1, children's parent-child communication scores and social competence scores show normal and nonnormal distribution. Histogram graphs were created and examined for each sub-dimension.

After the data distribution analysis, descriptive statistics (number of people, minimum, maximum, average, standard deviation) were calculated. Then the data were analysed in accordance with the research questions. The assumptions of the tests (homogeneity of normality and variances) were decided before the difference tests and the results were reported. Spearman correlation coefficient was calculated to determine the relationships between preschool children's mothers' communication and social competence.

\section{Results}

The findings are presented in three parts: the first part is including the results regarding social competence and communication status of mothers and children according to some demographic characteristics, the second one is the findings related to children's social competence and communication levels; and the last part is the findings related to relationship between children's social competence levels and communication with their mothers.

\section{Findings regarding social competence and communication status of mothers and children according to some demographic characteristics}

It was examined whether the social competence levels of the children included in the study differ significantly according to age, gender, and number of siblings and whether the communication status of the mothers with their children alter according to mothers' age and education level.

Kruskal Wallis Test results regarding communication scores of the children with their mothers considering their mothers`age are shown in Table 4. 
Table 4. Kruskal Wallis Test results calculated for mothers`communication levels regarding their age $(\mathrm{N}=323)$

\begin{tabular}{|c|c|c|c|c|c|c|}
\hline $\begin{array}{ll}\text { Scale } & \text { sub- } \\
\text { dimensions } & \end{array}$ & Mother`s Age & $\mathrm{n}$ & $\begin{array}{l}\text { Mean } \\
\text { Rank }\end{array}$ & $\mathrm{df}$ & $\chi^{2}$ & $\mathrm{p}$ \\
\hline \multirow{3}{*}{ Speaking } & 30 and below & 75 & 154,97 & \multirow{3}{*}{2} & \multirow{3}{*}{1,768} & \multirow{3}{*}{0,413} \\
\hline & Between 31-40 & 204 & 161,15 & & & \\
\hline & Above 41 & 44 & 177,93 & & & \\
\hline \multirow{3}{*}{ Listening } & 30 and below & 75 & 150,38 & \multirow{3}{*}{2} & \multirow{3}{*}{5,849} & \multirow{3}{*}{0,054} \\
\hline & Between 31-40 & 204 & 159,86 & & & \\
\hline & Above 41 & 44 & 191,75 & & & \\
\hline \multirow{3}{*}{ Message } & 30 and below & 75 & 169,84 & \multirow{3}{*}{2} & \multirow{3}{*}{2,179} & \multirow{3}{*}{0,336} \\
\hline & Between 31-40 & 204 & 156,29 & & & \\
\hline & Above 41 & 44 & 175,10 & & & \\
\hline \multirow{3}{*}{$\begin{array}{l}\text { Non-verbal } \\
\text { communication }\end{array}$} & 30 and below & 75 & 165,29 & \multirow{3}{*}{2} & \multirow{3}{*}{, 375} & \multirow{3}{*}{0,829} \\
\hline & Between 31-40 & 204 & 159,66 & & & \\
\hline & Above 41 & 44 & 167,26 & & & \\
\hline \multirow{3}{*}{ Empathy } & 30 and below & 75 & 164,55 & \multirow{3}{*}{2} & \multirow{3}{*}{2,959} & \multirow{3}{*}{0,228} \\
\hline & Between 31-40 & 204 & 156,57 & & & \\
\hline & Above 41 & 44 & 182,82 & & & \\
\hline \multirow{3}{*}{ Total } & 30 and below & 75 & 161,59 & \multirow{3}{*}{2} & \multirow{3}{*}{4,631} & \multirow{3}{*}{0,99} \\
\hline & Between 31-40 & 204 & 156,21 & & & \\
\hline & Above 41 & 44 & 189,57 & & & \\
\hline
\end{tabular}

When the information in Table 4 is examined, considering preschool children`s mothers` ages, it was determined that there was no significant difference in the scores they got from the following sub-dimensions; speaking $\left(\chi^{2}=1,768 ; p>.05\right)$, listening $\left(\chi^{2}=5,849 ; \mathrm{p}>.05\right)$, message $\left(\chi^{2}=2,179 ; \mathrm{p}>.05\right)$, non-verbal communication $\left(\chi^{2}=.375 ; \mathrm{p}>.05\right)$, empathy $\left(\chi^{2}=\right.$ $2,959 ; \mathrm{p}>.05)$ and communication total score $\left(\chi^{2}=4,631 ; \mathrm{p}>.05\right)$. It was seen that the communication was similar between the children and their mothers whose ages were below 30, between 31-40 and above 40. The results of Kruskal Wallis Test calculated in order to determine whether the communication of preschool children according to their mothers education level differed significantly or not were given in Table 5.

Table 5. Kruskal Wallis Test results calculated for mothers`communication levels regarding their education level $(\mathrm{N}=323)$

\begin{tabular}{|c|c|c|c|c|c|c|}
\hline $\begin{array}{ll}\text { Scale } & \text { sub- } \\
\text { dimensions }\end{array}$ & Mother`s Education Level & $\mathrm{n}$ & $\begin{array}{l}\text { Mean } \\
\text { Rank }\end{array}$ & $\mathrm{df}$ & $\chi^{2}$ & $\mathrm{p}$ \\
\hline \multirow[t]{3}{*}{ Speaking } & Secondary School and below & 90 & 169,43 & & & \\
\hline & High School & 112 & 167,91 & 2 & 2,768 & 0,251 \\
\hline & University and above & 121 & 151,00 & & & \\
\hline \multirow[t]{3}{*}{ Listening } & Secondary School and below & 90 & 162,91 & & & \\
\hline & High School & 112 & 165,39 & 2 & ,364 & 0,833 \\
\hline & University and above & 121 & 158,19 & & & \\
\hline \multirow[t]{3}{*}{ Message } & Secondary School and below & 90 & 162,09 & & & \\
\hline & High School & 112 & 165,21 & 2 & ,264 & 0,876 \\
\hline & University and above & 121 & 158,96 & & & \\
\hline Non-verbal & Secondary School and below & 90 & 168,79 & & & \\
\hline \multirow[t]{2}{*}{ Communication } & High School & 112 & 161,59 & 2 &, 810 & 0,667 \\
\hline & University and above & 121 & 157,33 & & & \\
\hline \multirow[t]{3}{*}{ Empathy } & Secondary School and below & 90 & 153,00 & & & \\
\hline & High School & 112 & 162,78 & 2 & 1,351 & 0,509 \\
\hline & University and above & 121 & 167,98 & & & \\
\hline Total & Secondary School and below & 90 & 168,79 & & & \\
\hline Communication & High School & 112 & 165,63 & 2 & ,372 & 0,830 \\
\hline Score & University and above & 121 & 158,21 & & & \\
\hline
\end{tabular}


When Table 5 is examined, it was found that there was no significant difference in children`s scores in terms of their mothers' education levels. The values for the sub-dimensions were as follows; speaking $\left(\chi^{2}=2,768 ; p>.05\right)$, listening $\left(\chi^{2}=, 364 ; p>.05\right)$, message $\left(\chi^{2}=, 264 ; p>\right.$ $.05)$, non-verbal communication $\left(\chi^{2}=, 810 ; p>.05\right.$, empathy $\left(\chi^{2}=1,351 ; p>.05\right)$. Similarly, children's communication with their mothers $\left(\chi^{2}=, 372 ; \mathrm{p}>.05\right)$ did not show any significant differences in terms of their mothers' education levels. It was determined that the communication levels of the children were similar in terms of their mothers` education levels (secondary school or less, high school, a university degree or above). The t-test was calculated in unrelated measurements regarding whether preschool children's social competence levels show a significant difference in terms of age or not, and the results are given in Table 6.

Table 6. T-test results in unrelated measurements calculated for preschool children`s social competence levels regarding age variable $(\mathrm{N}=323)$

\begin{tabular}{|c|c|c|c|c|c|c|}
\hline $\begin{array}{ll}\text { Scale } & \text { sub- } \\
\text { dimensions } & \end{array}$ & Children`s Age & $\mathrm{N}$ & $\overline{\mathrm{X}}$ & $\mathrm{S}_{\mathrm{x}}$ & $\mathrm{T}$ & $P$ \\
\hline \multirow[t]{2}{*}{ Social competence } & 4 & 143 & 176,67 & 26,04 & \multirow[b]{2}{*}{0,911} & \multirow[b]{2}{*}{0,363} \\
\hline & 5 & 180 & 179,44 & 28,04 & & \\
\hline \multirow{2}{*}{$\begin{array}{l}\text { Inward-oriented } \\
\text { problems }\end{array}$} & 4 & 143 & 46,26 & 12,94 & \multirow[b]{2}{*}{0,591} & \multirow[b]{2}{*}{0,555} \\
\hline & 5 & 180 & 47,09 & 12,20 & & \\
\hline \multirow{2}{*}{$\begin{array}{l}\text { Outward-oriented } \\
\text { problems }\end{array}$} & 4 & 143 & 48,48 & 12,72 & \multirow[b]{2}{*}{1,792} & \multirow[b]{2}{*}{0,074} \\
\hline & 5 & 180 & 46,08 & 11,35 & & \\
\hline \multirow{2}{*}{$\begin{array}{ll}\text { Total } & \text { Social } \\
\text { Competence } & \end{array}$} & 4 & 143 & 361,93 & 42,97 & \multirow[b]{2}{*}{0,922} & \multirow[b]{2}{*}{0,357} \\
\hline & 5 & 180 & 366,28 & 41,37 & & \\
\hline
\end{tabular}

When Table 6 is examined in terms of the sub-dimensions of social competence $\left(\mathrm{t}_{(321)}=0,911\right.$; $\mathrm{p}>0,05)$, inward-oriented problems $\left(\mathrm{t}_{(321)}=0,591 ; \mathrm{p}>0,05\right)$ and outward-oriented problems $\left(\mathrm{t}_{(321)}=1,792 ; \mathrm{p}>0,05\right)$, there was no significant difference. Similarly, social competence total scores $\left(\mathrm{t}_{(321)}=0.922 ; \mathrm{p}>0.05\right)$ did not show any significant differences regarding children ages. In other words, it was determined that the social competence levels of 4 and 5-year-olds were similar. The $\mathrm{t}$ test was calculated in unrelated measurements regarding whether preschool children`s social competence levels show a significant difference in terms of gender or not, and the results are given in Table 7.

Table 7. $\mathrm{T}$ test results in unrelated measurements calculated for preschool children`s social competence levels regarding gender variable $(\mathrm{N}=323)$

\begin{tabular}{|c|c|c|c|c|c|c|c|}
\hline $\begin{array}{l}\text { Scale } \\
\text { sub-dimensions }\end{array}$ & $\begin{array}{l}\text { Children's } \\
\text { Gender }\end{array}$ & $\mathbf{N}$ & $\overline{\mathbf{X}}$ & $\overline{\mathbf{S}_{\mathbf{x}}}$ & Sd & $\mathbf{t}$ & $\mathbf{P}$ \\
\hline \multirow[t]{2}{*}{ Social competence } & Girl & 152 & 181,89 & 28,80 & \multirow[b]{2}{*}{321} & \multirow[b]{2}{*}{2,309} & \multirow[b]{2}{*}{$0,002 *$} \\
\hline & Boy & 171 & 174,95 & 25,27 & & & \\
\hline \multirow{2}{*}{$\begin{array}{l}\text { Inward-oriented } \\
\text { problems }\end{array}$} & Girl & 152 & 46,53 & 12,51 & \multirow[b]{2}{*}{321} & \multirow[b]{2}{*}{0,264} & \multirow[b]{2}{*}{0,792} \\
\hline & Boy & 171 & 46,89 & 12,57 & & & \\
\hline \multirow{2}{*}{$\begin{array}{l}\text { Outward-oriented } \\
\text { problems }\end{array}$} & Girl & 152 & 46,18 & 12,14 & \multirow[b]{2}{*}{321} & \multirow[b]{2}{*}{1,353} & \multirow[b]{2}{*}{0,177} \\
\hline & Boy & 171 & 47,99 & 11,88 & & & \\
\hline \multirow{2}{*}{$\begin{array}{ll}\text { Total } & \text { Social } \\
\text { Competence }\end{array}$} & Girl & 152 & 369,18 & 43,10 & \multirow[b]{2}{*}{321} & \multirow[b]{2}{*}{1,954} & \multirow[b]{2}{*}{0,052} \\
\hline & Boy & 171 & 360,06 & 40,79 & & & \\
\hline
\end{tabular}

When Table 7 is examined it was found that there was a significant difference in preschool children`s social competence sub-dimension scores $\left(\mathrm{t}_{(321)}=2.309 ; \mathrm{p}<0.05\right)$ regarding gender. When the average scores were examined, it was determined that girls' social competence levels focusing on features such as cheerful, safe, patient, integrated, calm, pro-social, autonomous, and collaborative were higher than those of boys. However, it was found that 
there was no significant difference in children`s total scores of inward-oriented problem $\left(\mathrm{t}_{(321)}\right.$ $=0.264 ; \mathrm{p}>0.05)$, outward-oriented problem $\left(\mathrm{t}_{(321)}=1.353 ; \mathrm{p}>0.05\right)$ and social competence $\left(\mathrm{t}_{(321)}=1.954 ; \mathrm{p}>0.05\right)$ in terms of gender variable. In other words, it was determined that girls and boys were at similar levels regarding inward and outward-oriented problem behaviors. One-way analysis of variance was calculated for the social competence levels of the children participating in the study according to the number of siblings, and the results are given in Table 8 .

Table 8. The results of one-way analysis of variance calculated for preschool children`s social competence levels regarding the number of their siblings $(\mathrm{N}=323)$

\begin{tabular}{|c|c|c|c|c|c|c|c|}
\hline $\begin{array}{l}\text { Scale sub- } \\
\text { dimensions }\end{array}$ & Number of Siblings & $\mathbf{N}$ & $\overline{\mathbf{X}}$ & $\mathbf{S}_{\mathbf{x}}$ & Sd & $\mathbf{F}$ & $\mathbf{P}$ \\
\hline \multirow[t]{3}{*}{ Social competence } & Single & 80 & 176,98 & 25,14 & \multirow{3}{*}{$2(322)$} & \multirow{3}{*}{0,812} & \multirow{3}{*}{0,445} \\
\hline & One & 184 & 177,46 & 27,51 & & & \\
\hline & 2 and more & 59 & 182,27 & 28,78 & & & \\
\hline \multirow{3}{*}{$\begin{array}{l}\text { Inward-oriented } \\
\text { problems }\end{array}$} & Single & 80 & 178,22 & 27,17 & \multirow{3}{*}{$2(322)$} & \multirow{3}{*}{0,486} & \multirow{3}{*}{0,616} \\
\hline & One & 184 & 47,43 & 13,62 & & & \\
\hline & 2 and more & 59 & 46,85 & 12,23 & & & \\
\hline \multirow{3}{*}{$\begin{array}{l}\text { Outward-oriented } \\
\text { problems }\end{array}$} & Single & 80 & 45,36 & 11,97 & \multirow{3}{*}{$2(322)$} & \multirow{3}{*}{0,844} & \multirow{3}{*}{0,431} \\
\hline & One & 184 & 46,72 & 12,52 & & & \\
\hline & 2 and more & 59 & 47,61 & 11,48 & & & \\
\hline \multirow{3}{*}{$\begin{array}{l}\text { Total Social } \\
\text { Competence }\end{array}$} & Single & 80 & 47,53 & 12,52 & \multirow{3}{*}{$2(322)$} & \multirow{3}{*}{1,095} & \multirow{3}{*}{0,336} \\
\hline & One & 184 & 45,31 & 11,13 & & & \\
\hline & 2 and more & 59 & 47,14 & 12,02 & & & \\
\hline
\end{tabular}

When Table 8 is examined it was found that there was no significant difference in preschool children's social competence regarding the variable of sibling. The sub-dimension scores of social competence were $\left(\mathrm{F}_{2(322)}=0,812 ; \mathrm{p}>0,05\right)$, for inward-oriented problem were $\left(\mathrm{F}_{2(322)}\right.$ $=0,486 ; \mathrm{p}>0,05)$ and outward-oriented problem were $\left(\mathrm{F}_{2(322)}=0,844 ; \mathrm{p}>0,05\right)$. It was determined that children`s social competence total scores $\left(F_{2(322)}=1,095 ; p>0,05\right)$ did not show any significant differences regarding the number of siblings. In other words, it is seen that the social competence levels of children were similar in children with no siblings, with one sibling and with two or more siblings.

\section{Findings related to children's social competence and communication levels}

The descriptive statistics results which are calculated to determine the social competence levels of preschool children are given in Table 9.

Table 9. Descriptive statistics regarding children's social competence levels $(\mathrm{N}=323)$

\begin{tabular}{lllllll}
\hline SCBAS & Item & $\mathrm{N}$ & Lowest & Highest & $\overline{\mathrm{X}}$ & $\mathrm{S}_{\mathrm{x}}$ \\
\hline Social competence & 40 & 323 & 106,00 & 239,00 & 178,22 & 27,17 \\
Inward-oriented & 20 & 323 & 20,00 & 82,00 & 46,72 & 12,52 \\
Outward-oriented & 20 & 323 & 26,00 & 91,00 & 47,14 & 12,02 \\
\hline Total & 80 & 323 & 264,00 & 457,00 & 364,35 & 42,08 \\
\hline
\end{tabular}

According to the information given in Table 9, it is seen that the scores children obtained from the items in the social competence sub-dimension of Social Competence and Behavior Assessment Scale varied between 106,00 and 239,00 and the average score was calculated as $178,22( \pm 27,17)$. These subscale scores, which measure children's characteristics such as being cheerful, reliable, patient, integrated, calm, prosocial, autonomous, and collaborative show children's high social competence. 
It was found that children's inward-oriented problem scores were between 20.00 and 82.00, and the mean was 46.72 ( \pm 12.52$)$. The scores obtained from this sub-dimension focusing on depressive, anxious, isolated, and dependent characteristics of preschool children indicate that children have moderate inward-oriented problems.

It was determined that the scores of the children's outward-oriented problem sub-dimension varied between 26.00 and 91.00, and the average was calculated as $47.14( \pm 12.02)$. The scores obtained from this dimension focusing on children's angry, aggressive, selfish, and opposing behaviors indicate that the children participating in the study showed moderate outward behavior.

It is seen that, in Table 4, the total social competence scores of preschool children varied between 264.00 and 457.00 and the average was calculated as $364.35( \pm 42.08)$. Total score calculation was carried out by inverse coding of inward-oriented problem and outwardoriented problem sub-dimensions.

Table 10 shows the descriptive statistics for the communication levels of the mothers with their children.

Table 10. Descriptive statistics of mothers' communication level with their children $(\mathrm{N}=323)$

\begin{tabular}{lllllll}
\hline PCCAT & Item & $\mathrm{N}$ & Lowest & Highest & $\overline{\mathrm{X}}$ & $\mathrm{S}_{\mathrm{x}}$ \\
\hline Speaking & 8 & 323 & 18,00 & 34,00 & 26,57 & 2,17 \\
Listening & 6 & 323 & 15,00 & 32,00 & 25,86 & 2,61 \\
Message & 8 & 323 & 16,00 & 35,00 & 26,03 & 3,12 \\
Non-verbal & 6 & 323 & 13,00 & 29,00 & 21,43 & 2,23 \\
Empathy & 9 & 323 & 17,00 & 43,00 & 32,82 & 3,84 \\
\hline Total & 37 & 323 & 84,00 & 149,00 & 132,73 & 8,22 \\
\hline
\end{tabular}

When the information in Table 10 is examined, it is seen that mothers' scores obtained from their communication with their children regarding sub-dimensions of speaking, listening, message, nonverbal communication and empathy were given. Mothers' speaking scores in communication with their children ranged from 18,00 to 34,00 , with an average of 26,57 ( \pm 2,17). Listening sub-dimension scores vary between 15.00 and 32.00 and the average was calculated as $25,86( \pm 2.61)$; the message sub-dimension scores vary between 16.00 and 35.00 and the average was $26,03( \pm 3,12)$; the scores in the nonverbal communication subdimension were between 13,00 and 29,00 and the average was 21,43 ( $\pm 2,23)$; empathy subscale scores were between 17,00 and 43,00, and the average was calculated as 32,82 ( \pm $3,84)$. It was determined that the communication scores of the mothers with their children varied between 84,00 and 149,00 and the average was calculated as $132,73( \pm 8,22)$.

\section{Findings related to the relationship between children's social competence levels and mothers' communication with them}

The relationships between mothers' communication with their children and children's social competence levels within their sub-dimensions were calculated, and then the relationships between the two variables were determined. Spearman's rho correlation coefficient was used in the calculations and the results are shown in the following three Tables (Table 11, Table 12 and Table 13). 
Table 11. The relationship between mothers' communication with their children and communication sub-dimensions $(\mathrm{N}=323)$

\begin{tabular}{|c|c|c|c|c|c|c|}
\hline $\begin{array}{l}\text { PCCAT } \\
\text { Sub-dimensions }\end{array}$ & Speaking & Listening & Message & $\begin{array}{l}\text { Non-verbal } \\
\text { communication }\end{array}$ & Empathy & Total \\
\hline Speaking & - & & & & & \\
\hline Listening & ,282** & - & & & & \\
\hline Message & ,113* &,- 001 & - & & & \\
\hline $\begin{array}{l}\text { Non-verbal } \\
\text { communication }\end{array}$ & ,046 &, $146 * *$ &, $195 * *$ & - & & \\
\hline Empathy & ,316** & ,354** & ,008 & $-0,16$ & - & \\
\hline Total &, $588 * *$ &, $582 * *$ & ,477** &, $377 * *$ & ,655** & - \\
\hline
\end{tabular}

When Table 11 is examined, it is seen that there is a positive and high-level relationship between mother-child communication total scores and empathy sub-dimension $(r=0.655 ; \mathrm{p}$ $<0.01$ ). There were positive and moderate relationships between mother-child communication total scores and and sub-dimension of speaking $(\mathrm{r}=0.588 ; \mathrm{p}<0.01)$, the sub-dimensions of listening $(r=0.582 ; p<0.01)$; message $(n=0.477 ; p<0.01)$. However, there was a positive and low level of relationship between mother-child communication total scores and the nonverbal communication sub-dimension scores $(r=0.377 ; \mathrm{p}<0.01)$.

There was a positive and moderate relationship between mother-child communication empathy sub-dimension and speaking sub-dimension $(\mathrm{r}=0.316 ; \mathrm{p}<0.01)$; empathy subdimension and listening sub-dimension $(r=0.354 ; \mathrm{p}<0.01)$. However, there were positive and low relationship between mother-child communication listening sub-dimension and speaking sub-dimension $(\mathrm{r}=0.282 ; \mathrm{p}<0.01)$; message sub-dimension and speaking subdimension $(\mathrm{r}=0.113 ; \mathrm{p}<0.05)$; nonverbal communication sub-dimension and listening subdimension $(\mathrm{r}=0.146 ; \mathrm{p}<0.01)$; nonverbal communication sub-dimension and message subdimension $(r=0.195 ; \mathrm{p}<0.01)$.

There were positive and moderate relationships between mother-child communication total scores and sub-dimension of speaking $(\mathrm{r}=0.588 ; \mathrm{p}<0.01)$, the sub-dimensions of listening $(\mathrm{r}$ $=0.582 ; \mathrm{p}<0.01)$; message $(\mathrm{n}=0.477 ; \mathrm{p}<0.01)$. However, there was a positive and low level of relationship between mother-child communication total scores and the non-verbal communication sub-dimension scores $(r=0.377 ; \mathrm{p}<0.01)$.

It was determined that there was no significant relationship between message-listening, nonverbal-speaking, empathy-message. There was no significant relationship between empathy and nonverbal $(\mathrm{p}>0.05)$.

Table 12. The relationship between children's social competence levels and social competency sub-dimensions $(\mathrm{N}=323)$

\begin{tabular}{|c|c|c|c|c|}
\hline $\begin{array}{l}\text { SCBAS } \\
\text { Sub-dimensions }\end{array}$ & $\begin{array}{l}\text { Social } \\
\text { competence }\end{array}$ & $\begin{array}{l}\text { Inward-oriented } \\
\text { problems }\end{array}$ & $\begin{array}{l}\text { Outward-oriented } \\
\text { problems }\end{array}$ & Total \\
\hline Social competence & - & & & \\
\hline Inward-oriented problems &,$- 462 * *$ & - & & \\
\hline Outward-oriented problems &,$- 384 * *$ &, $551 * *$ & - & \\
\hline Total &, $893 * *$ &,$- 754 * *$ &,$- 698 * *$ & - \\
\hline
\end{tabular}

$\left({ }^{*} \mathrm{p}<0,05\right.$ and $\left.* * \mathrm{p}<0,01\right)$

As it is seen in Table 12, there was a positive and high-level relationship between the total scores of children's social competence and social competence sub-dimension $(r=0.893 ; p$ 
$<0.01)$. It was determined that there was a negative and high-level relationship between children's total social competence scores and inward oriented problems $(r=-0,754 ; p<0,01)$; and outward oriented problems $(r=-0,698 ; \mathrm{p}<0,01)$.

Table 13. The relationship between children's social competence levels and mothers' communication with their children $(\mathrm{N}=323)$

\begin{tabular}{lllll}
\hline $\begin{array}{l}\text { PCCAT } \\
\text { Subdimensions }\end{array}$ & $\begin{array}{l}\text { Social } \\
\text { competence }\end{array}$ & $\begin{array}{l}\text { Inward-oriented } \\
\text { problems }\end{array}$ & $\begin{array}{l}\text { Outward-oriented } \\
\text { problems }\end{array}$ & $\begin{array}{l}\text { Total } \\
\text { Social } \\
\text { competence }\end{array}$ \\
\hline $\begin{array}{llll}\text { Speaking } \\
\text { Listening }\end{array}$ &, $199^{* *}$ &,- 104 &,$- 168^{* *}$ &, $196^{* *}$ \\
Message &, $195^{* *}$ &,$- 176^{* *}$ &,$- 159^{* *}$ &, $224^{* *}$ \\
Non-verbal communication &, $196^{* *}$ &,$- 254^{* *}$ &,$- 236^{* *}$ &, $264^{* *}$ \\
Empathy &, $126^{*}$ &,$- 180^{* *}$ &,$- 122^{*}$ &, $159^{* *}$ \\
Total &, $277^{* *}$ &,$- 143^{*}$ &,$- 126^{*}$ &, $257^{* *}$ \\
\hline
\end{tabular}

$* \mathrm{p}<0,05$ and ${ }^{* *} \mathrm{p}<0,01$

When the information in Table 13 was examined, it was found that there was a positive and moderate relationship between mothers' communication with their children and their total social competence levels $(\mathrm{r}=0,411 ; \mathrm{p}<0.01)$. Similarly, there was a positive and moderate relationship between mothers' communication with their children and children's social competence $(r=0,376 ; p<0.01)$; but there was a negative and moderate relationship between mothers' communication with their children and the sub-dimensions of inward-oriented problems $(r=-0.313 ; p<0.01)$ and outward-oriented problems $(r=-0.300 ; p<0,01)$.

It was determined that there was a positive but low-level relationship between mother-child communication subscale of speaking and children's social competence subscale $(r=0.199 ; \mathrm{p}$ $<0.01)$ and total scores $(r=0.196 ; \mathrm{p}<0.01)$. However, it was found that there was a negative and low-level relationship between the speech subdimension of mother-child communication and outward oriented problems $(\mathrm{r}=-0,168 ; \mathrm{p}<0,01)$. In addition, there was no significant relationship? between mother-child communication subscale of speaking and inward oriented problems $(\mathrm{r}=-0,104 ; \mathrm{p}<0,01)$

It was determined that there was a positive but low-level relationship between mother-child communication subscale of listening and children's social competence subscale $(r=0.195 ; \mathrm{p}$ $<0.01)$ and total scores $(r=0.224 ; \mathrm{p}<0.01)$. However, it was found that there was a negative and low-level relationship between the listening subdimension of mother-child communication and inward oriented problems $(r=-0,176 ; p<0,01)$ and outward oriented problems $(\mathrm{r}=-0,159 ; \mathrm{p}<0,01)$. Mother-child communication subscale of message and children's social competence subscale had also a positive but low-level relationship ( $\mathrm{r}=$ 0.196; $\mathrm{p}<0.01)$ and total scores $(\mathrm{r}=0.264 ; \mathrm{p}<0.01)$. However, it was found that there was a negative and low-level relationship between the message subdimension of mother-child communication and inward oriented problems $(r=-0,254 ; \mathrm{p}<0,01)$ and outward oriented problems $(r=-0,236 ; p<0,01)$. Another positive but low-level relationship found between mother-child communication subscale of nonverbal communication and children's social competence subscale $(r=0.126 ; p<0.05)$ and total scores $(r=0.159 ; p<0.01)$. However, it was found that there was a negative and low-level relationship between the nonverbal communication subdimension of mother-child communication and inward oriented problems $(\mathrm{r}=-0,180 ; \mathrm{p}<0,01)$ and outward oriented problems $(\mathrm{r}=-0,122 ; \mathrm{p}<0,05)$. Moreover, between mother-child communication subscale of empathy and children's social competence subscale there was a positive and low-level relationship $(r=0.277 ; p<0.01)$ and total scores $(r=0.257$; $\mathrm{p}<0.01)$. On the other hand, it was also found that there was a negative and low-level 
relationship between the empathy subdimension of mother-child communication and inward oriented problems $(r=-0,143 ; p<0,05)$ and outward oriented problems $(r=-0,126 ; p<0,05)$.

\section{Conclusion and Discussion}

In the present study, the relationship between 4-5-year-old preschool children's social competence levels and their ability to communicate with their mothers was examined.

\section{the findings of mothers`and their children's social competence and communication skills were examined according to some demographic characteristics}

When the results of the mothers' communication status regarding the mother's age and education level were examined, it was found that there was no significant difference in mothers' skills of speaking, listening, message, non-verbal communication, empathy and communication regarding age and education level. Arabaci and Omeroglu (2013) determined that there were no significant relationships ? among speaking, listening, non-verbal communication, empathy sub-dimensions. These findings are parallel to the results of the present study. But there was a significant difference in the message sub-dimension scores of the mothers in their study. It is seen that the older the mother gets, the more successful she is in the sub-dimension of message.

Dereli and Dereli (2017), on the other hand, examined the parent-child relationship in their study and determined that while the parent-child relationship did not show a significant difference in terms of establishing positive relationships and children's psycho-social development regarding mother`s education status, mothers who finished primary school had more conflicts with their children.

The following results were obtained according to the social competence levels of the children regarding their age, gender, and number of siblings they had. (When social competence levels of the children were analyzed according to the age, gender, and number of siblings three different results were obtained.) The first one was that social competence of the children forming the sample group showed no significant difference in terms of social competence, inward-oriented problems, outward-oriented problems and total social competence regarding age. In other words, it was determined that the social competence levels of 4- and 5-year-old children were similar. Aydener (2016), Bozkurt (2016) and Surmeli (2018) examined the differentiation of preschool children's social competence, anger-aggression and anxietyintroversion/anxiety levels regarding age variable and found no significant difference. These results support the result of the present study. On the other hand, Chen and Jiang (2002) examined whether the social competence, emotional and behavioral problems of children in preschool years differ according children's age or not and they found that social competence behaviors increase with age. Similar behaviors were observed in children's anger-aggression and anxiety-withdrawal behaviors regarding age. Vahedi, Farrokhi, and Farajian (2012) examined the social competence and behavioral problems of children attending kindergarten and found that there was a significant linear trend between progress in proficiency and increasing age. So, there was a decrease in social problems which was leading to an increase in the social competence of children between the ages of 2 to 5.5.

There was a significant difference in children`s social competence sub-dimension scores regarding gender. When the average scores were examined, it was determined that girls' social competence levels focusing on cheerful, safe, patient, integrated, calm, pro-social, autonomous, and collaborative characteristics were higher compared to boys. Corapci, Aksan, 
Arslan-Yalcin \& Yagmurlu (2010), Ciftci Topaloglu (2013), Yarali \& Ozkan (2016), Surmeli (2018), Uygun \& Kozikoglu (2019) \& Liman (2020) found in their study that the social competence levels of girls were higher than boys. Chen and Jiang (2002) revealed in their study that boys were at higher levels in anger-aggression and anxiety-withdrawal behaviors than girls, while they were at a lower level in social competence behaviors. The results of these studies were also in line with the results of this study.

It was determined that there was no significant difference regarding social competence, inward-oriented problems, outward-oriented problems and total social competence scores between boys and girls. It was determined that girls and boys were at similar levels showing inward-oriented problems and outward-oriented problems behaviors. In their studies, Aydener (2016) and Bozkurt (2016) found that preschool children's social competence, anxietyintroversion and anger-aggression levels were not statistically significant in terms of their gender. This result also supports the results of the present study. However, Schmidt, Demulder, and Denham (2002) conducted a longitudinal study and followed children`s attachment and social competence levels from age 3 till age 4-5. They examined the relationship between family stress and social-emotional competencies in these children and found that boys were more aggressive and anxious than girls in kindergarten class.. However, in this study, it was determined that there was no significant difference between girls and boys.

According to the number of siblings of preschool children, there was no significant difference in the total scores of social competence, inward-oriented problems and outward-oriented problems and social competence. In other words, it was determined that the social competence levels of children who were the only child, who had one sibling, had two or more siblings were similar. Although this is an unexpected result, it might be due to the lack of equality in the distribution of the number of siblings of the children in the study group. In the study of Liman (2020) social competence and behavioral status of preschool children were examined according to the number of siblings they had and the social competence levels of children were found statistically meaningful. It was also found that there was no difference in the anger-aggression and anxiety-introversion behavior scores of the children regarding the number of siblings. Although this study differs in terms of social competence, it supports the results of the study in terms of behavioral problems. Uygun and Kozikoglu (2019) conducted a study and found no significant difference in social competence and anger-aggression behavior dimensions of preschool children according to the number of siblings, but the anxiety-introversion behaviors of children with three or more siblings were statistically meaningful compared to those who were single child or had one sibling.

\section{the findings related to children's social competence levels and their ability to communicate with their mothers:}

According to children's scores obtained from Social Competence and Behavior Assessment Scale, it is seen that their social competence average scores were high and the mean of inward and outward oriented problems were close and low. In other words, it is seen that the social competence levels of the children in the study that express their features such as being cheerful, reliable, patient, integrated, calm, pro-social, autonomous, and cooperative were high. On the other hand, the inward and outward oriented problems were lower. According to Prinstein and La Greca (2004), the increase in children's social competence skills supports their social skills positively and prevents them from negative situations such as introversion and anxiety. Gultekin Akduman, Gunindi ve Turkoglu (2015) determined in their 
study that as children's social competence levels increased, their problem behaviors decreased. In addition, Mendez, Fantuzzo, and Cicchetti (2002) found that children with high social adaptation levels were more compatible with their peers in their play activities, communicate effectively, and children with social incompatibility exhibited more behavioral problems. These results are in parallel with the results of the study.

In line with the answers of the mothers participated in the study, when the mean scores of the total mother-child communication and sub-dimensions (speaking, listening, message, nonverbal communication and empathy) were examined, it was seen that they obtained the highest scores from empathy and speaking sub-dimensions. In the study conducted by Arabaci and Omeroglu (2013), it was observed that the highest scores from the speech and empathy sub-dimensions were also similar. In addition, although listening, message and nonverbal communication scores are very close to each other, they are lower than empathy and speaking scores. Although empathy scores are high, it is challenging to see that listening and message scores are low.

There was a positive and high relationship between communication total scores and subdimensions of mother's communication (speaking, listening and empathy) with their children. It can be said that the necessary skills in establishing effective communication skills are effective listening, speaking and empathy. Another result of the study is that when the relationship between the total scores of mothers' communication with their children and the sub-dimensions of message and non-verbal communication was examined, a moderately significant relationship was found. In other words, it can be said that message and non-verbal communication skills are less important than other skills (listening, speaking and empathy) in effective communication.

A positive and moderate relationship found between speaking and empathy sub-dimensions of mothers' communication with their children suggests that speaking has an important place in empathy skills and gives rise to thought of this result as an expected one. The same is true for the relationship between empathy and listening skills. In addition, a low-level significant relationship was found between speaking and listening skills.

There is a positive and high relationship between children's social competence total scores and the sub-dimension of social competence of Social Competence and Behavior Assessment Scale that is applied. It was determined that there was a negative and high-level relationship between children's social competence total scores and inward and outward oriented problems. In other words, as the social competence levels of children increased, their inward and outward oriented problems decreased. The fact that children have a high level of social competence suggests that their inward and outward oriented behavior problems decrease. In addition, as seen in the findings, although inward and outward orientation mean scores are close, it is observed that outward behaviors such as being angry, aggressive, selfish and having opposing behaviors are higher than being depressive, anxious, isolated and having dependent characteristics. Similar to this result, in the study of Cai, Kaiser and Hancock (2004), it is stated that outward-oriented problems are higher than inward-oriented problems. In the study conducted by Dere Ciftci (2016) in order to determine the relationship between 5-6-year-old preschool children's communication with their parents and their social skills and behavioral problems. The study revealed that children whose positive relationship scores increased as they built positive relationship with their parents, their skills of social cooperation and social interaction increased too, and so do skills and overall social skills and competence scores. Nevertheless, in the same study, when the relationship between parent- 
child relationship and behavioral problems was examined, it was noted that there was a significant relationship between dimension of parents' conflict and behavioral problems. Gur and et al. (2015) found in their study an inverse relation between social competence and anger-aggression and social competence and anxiety-introversion, anger-aggression that was conducted to evaluate the social competence and behavior problems of 48-60-month-old children attending preschool education institutions. They also found that there was a positive and significant relationship between anxiety and introversion. As children's scores of childparent conflict increased, their scores of outward orientation, antisocial behavior and total behavior increased too. In their study, Yarali and Ozkan (2016) found that children with high social competence levels had lower levels of anger-aggression and anxiety-introversion. Sirois, Bernier and Lemelin (2019) found that children with inward and outward oriented problems had less social competence and less prosocial behavior.

\section{When the relationship between children's social competence levels and their communication with mothers is examined:}

As the important result of this study there was a positive and moderate relationship between the social competence total scores' of children and mother's communication total scores with them. There was a significant relationship between mother's communication total scores and sub-dimensions of social competence regarding children. A moderately positive and significant relationship was found between mother-child communication total score and social competence sub-dimension scores, while a moderately negative relationship was found between internal and external-oriented behavioral problems. In other words, as the communication levels of mothers with their children increase, the social competence of the children increases as internal and external oriented problem behaviors decrease. As mothers' ability to speak effectively with their children provide positive interaction, it can be thought that children become cheerful, patient, calm, pro-social, self-confident, autonomous, and cooperative. It can be thought that parents who can talk and empathize effectively with their children may decrease their children's inward and outward oriented behaviors as they affect their social competence positively. Denham, Renwick and Holt (1991) have shown that mother-child interaction affects children's positive social behavior, assertiveness and sadness consistently. Zhang (2011) examined the role of the parent-child relationship of preschool children in children's social competencies and observed that there was a positive relationship between mother-child relationship, father-child relationship, and children's social competencies.

It was found that there was a positive and low relationship between children's total social competence and sub-dimension scores and their parents' sub-dimension scores of message. In addition, it is seen that there is a negative and low-level relationship between the message sub-dimension of parent-child communication and the inward and outward oriented problems. In other words, it can be said that the messages that mothers give to their children positively affect the social competence levels of children, albeit slightly, but partially reduce the internal and external oriented behavior problems. It was determined that there were positive and lowlevel relationships between children's social competence sub-dimension and social competence total score and parents' sub-dimension of empathy. This suggests that the ability of parents to empathize with their children increases their children's ability to be cheerful, safe, patient, calm, prosocial, autonomous, and cooperative. Berk (2013) stated that "when children and their parents establish close relationships, when they encourage their children express their feelings and when they show empathic and sensitive attention to their children's emotions, then their children respond to others' stress similarly" (pp. 371). 
To diversify the relevant study group, the related scales can be applied to parents separately and the results of the differences in communication can be analysed. The study can also be methodically diversified. In this study, general survey method is used and parents were asked to fill in the forms. In future studies, the data group can be kept in a limited number and can provide more detailed information by using both qualitative and mixed designs. Focus group meetings or individual interviews can be held with families.

\section{References}

Akgun, E., \& Yesilyaprak, B. (2010). The Reliability and Validity of Turkish Form of the Child Parent Relationship Scale. Balikesir University The Journal of Social Sciences Institute, 13(24), 44-53.

Alink, L. R. A., Mesman, J., Zeijl, J., Stolk, M. N., Juffer, F., Koot, H. M., \& Van IJzendoorn, M. H. (2006). The early childhood aggression curve: Development of physical aggression in 10-to-50-month-old children. Child Development, 77, 954-966. https://doi.org/10.1111/j.1467-8624.2006.00912.x

Anme, T., Shinohara, R., Sugisawa, Y., Tong, L., Tanaka, E., Watanabe, T., Onda, Y., Kawashima, Y., Hirano, M., Tomisaki, E., Mochizuki, H., Morita, K., Gan-Yadam, A., Yato, Y., Yamakawa, N. \& Japan Children's Study Group (2010). Gender differences of children's social skills and parenting using Interaction Rating Scale (IRS). Procedia Social and Behavioral Sciences, 2, 260-268. Doi: 10.1016/j.sbspro.2010.03.008

Anthony, L. G., Anthony, B. J., Glanville, D. N., Naiman, D. Q., Waanders, C. \& Shaffer, S. (2005). The relationships between parenting stress, parenting behaviour and preschoolers' social competence and behaviour problems in the classroom. Infant and Child Development, 14(2), 133-154. https://doi.org/10.1002/icd.385

Arabaci, N. (2011). Validity and reliability analysis of Parent-Child Communication Assessment tool (ABÇIDA). Unpublished Phd. Gazi Unıversity Education Sciences Institute, Ankara.

Arabaci, N. \& Omeroglu, E. (2013). 48-72 A Research on the communication of parents with their 48-72 months old children in terms of certain variables. Selcuk University Journal of Institute of Social Sciences, 30, 41-53.

Aral, N. \& Kadan, G. (2018). Sosyal gelişim. In N. Aral \& F. Temel (Eds.), Çocuk Gelişimi [Social development. In N. Aral \& F. Temel (Eds.), Child Development] (ss. 235-262). Ankara: Hedef.

Ashdown, D. M. \& Bernard, M. E. (2012). Can explicit instruction in social and emotional learning skills benefit the social-emotional development, well-being and academic achievement of young children? Early Childhood Education Journal, 39, 397-405. https://doi.org/10.1007/s10643-011-0481-x

Aunola, K. \& Nurmi, J. (2005). The role of parenting styles in children's problem behavior. Child Development, $\mathbf{7 6 ( 6 )}$, 1144-1159. Retrieved from http://www.jstor.org/stable/3696624

Aydener, M. K. (2016). Examination of problem behaviors in preschool children in terms of parents and teachers' opinions. Unpublished Master Thesis. Eastern Mediterranean University, Teaching and Research Institute, North Cyprus.

Bayindir, D., Guven, G., Sezer, T. Aksin-Yavuz, E. \& Yilmaz, E. (2017). The relationship between maternal acceptance-rejection levels and preschoolers' social competence and emotion regulation skills. Journal of Education and Learning, 6(2), 305-316. http://doi.org/10.5539/jel.v6n2p305 
Berk, L. E. (2013). Erken çocuklukta sosyal duygusal gelişim. (Çev. Ed. N. Işıkoğlu Erdoğan). Bebekler ve çocuklar, doğum öncesinden orta çocukluğa. [Social emotional development in early childhood education. (Translation N. Isikoglu Erdogan). Infants, children and adolescents. Ankara: Nobel.]

Bozkurt, E. (2016). The study of the relationship between preschool children's emotional understanding skills and their social competence levels. Unpublished Master Thesis. Necmettin Erbakan University, Institute of Educational Sciences, Konya.

Burt, K. B., Obradović, J., Long, J. D., \& Masten, A. S. (2008). The interplay of social competence and psychopathology over 20 years: Testing transactional and cascade models. Child Development, 79(2), 359-374. https://doi.org/10.1111/j.14678624.2007.01130.x

Buyukozturk, S. (2016). Sosyal bilimler için veri analizi el kitabı. Istatistik, araştırma deseni SPSS uygulamalarl ve yorum. [Handbook of social sciences for data analyse. Statistics, research design SPSS applications and interpretation. Ankara: Pegem]

Buyukozturk, S., Cakmak, E.K., Akgun, O.E, Karadeniz, S. \& Demirel, F. (2016). Bilimsel Araştırma Yöntemleri. [Scientific research methods.] Ankara: Pegem.

Cai, X., Kaiser, A. P., \& Hancock, T. B. (2004). Parent and teacher agreement on Child Behavior Checklist Items in a sample of preschoolers from low-income and predominantly African American families. Journal of Clinical Child and Adolescent Psychology, 33(2), 303-312. http://dx.doi.org/10.1207/s15374424jccp3302_12

Chen, Q. \& Jiang, Y. (2002). Social competence and behavior problems in Chinese preschoolers, Early Education and Development, 13(2), 171-186, Doi: 10.1207/ s15566935eed1302_4, https://doi.org/10.1207/s15566935eed1302_4

Chen, X. \& French, D. C. (2008). Children's social competence in cultural context. Annual Review of Psychology, https://doi.org/10.1146/annurev.psych.59.103006.093606

Cohen, J. (2001). Social and emotional education: Core concepts and practices. In J. Cohen (Eds.). The Social Emotional Education of Young Children. (pp. 1-36). New York: Teachers College.

Cohn, D. A. (1990). Child-mother attachment of six year olds and social competence at school. Child Development, 61, 152162. https://doi.org/10.1111/j.14678624.1990.tb02768.x

Ciftci Topaloglu, Z. (2013). The study of the relationship between the social competence, aggression and anxiety levels of 4-5 year old children and their parents' perception of parental self-efficacy. Unpublished Master Thesis. Pamukkale University, Institute of Educational Sciences, Denizli.

Corapci, F., Aksan, N., Arslan-Yalcin, D., \& Yagmurlu, B. (2010). Emotional, behavioral and social adjustment screening at school entry: social competence and behavior evaluation-30 scale. Turkish Journal of Child and Adolescent Mental Health, 17(2), 63-74.

Darling-Churchill, K. E. \& Lippman, L. (2016). Early childhood social and emotional development: Advancing the field of measurement. Journal of Applied Developmental Psychology, 45, 1-7. https://doi.org/10.1016/j.appdev.2016.02.002

Davis-Kean, P. E. \& Sandler, H. M. (2001). A meta-analysis of measures of self-esteem for young children: A framework for future measures. Child Development, 72 (3), 887906. 10.1111/1467-8624.00322

Denham, S.A., Renwick, S.M. \& Holt, R.W. (1991). Working and playing together: Prediction of preschool social-emotional competence from mother - child interaction, 
Child Development, $\quad 62, \quad 242-\quad 249 . \quad$ https://doi.org/10.1111/j.14678624.1991.tb01528.x

Dere Ciftci, H. (2016). Study of the relationship between 5-6 year-old pre-school children's social skills and behavior problems. The Journal of Academic Social Science Studies / International Journal of Social Science, 42, 171-191, Winter III. http://dx.doi.org/10.9761/JASSS3170

Dere Ciftci, H. (2018). Sosyal-duygusal gelişim alanı destek programları. (Editör: F. Temel \& N. Aral) Gelişimsel destek programlar: Gelişim alanlarına göre uygulama örnekleri. (ss. 163-200). [Social-emotional development support programs. In F. Temel \& N. Aral (Eds.) Developmental support programs: Application examples according to development areas. (pp. 163-200).] Ankara: Hedef.

Dereli, E., \& Dereli, B. M. (2017). Ebeveyn-çocuk ilişkisinin okul öncesi dönem çocukların psikososyal gelişimlerini yordaması. [The Prediction of Parent- Child Relationship on Psychosocial Development in Preschool Children] Yüzüncü Yıl Üniversitesi Eğitim Fakültesi Dergisi, 14(1), 227-258.

Deveci, F. (2011). The research about the difference between high-school students in their social support levels and styles of making decisions. Cukurova University, Unpublished master dissertation, Adana.

Diener, M. L., \& Kim, D.-Y. (2004). Maternal and child predictors of preschool children's social competence. Journal of Applied Developmental Psychology, 25(1), 3-24. http://dx.doi.org/10.1016/j.appdev.2003.11.006

Durmusoglu Saltal1, N. \& Arslan, E. (2012). Parent's attitudes as a predictor of preschoolers' social competence and introverted behavior. Ilkogretim Online, 11 (3), 729-737.

Gander, J. M. \& H. W. Gardiner (2010). Child and adolescent development. Translation: Ali Dönmez \& Nermin Celen, Ankara: İmge Bookstore.

Gresham, F. M. \& Reschly, D. J. (1987). Dimensions of social competence. Method factors in the assessments of adaptive behavior, social skills and peer acceptance. Journal of School Psychology, 25(4), 367-81. https://doi.org/10.1016/0022-4405(87)90038-0

Gulay-Ogelman, H. \& Ciftci-Topaloglu, Z. (2014). Monitoring the relationships between social competence, aggression, anxiety levels of 4-5 year old children and their mother and father's parental perceptions of self efficacy, Abant Izzet Baysal University Journal of Faculty of Education, 14(1), 241 - 271. http://dx.doi.org/10.17240/aibuefd.2014.14.1-5000091511

Gultekin Akduman, G., Gunindi, Y. \& Turkoglu, D. (2015). The investigation of the relations between social skills level and behavioral problems in preschool children. The Journal of International Social Research, 8(37), 673-683. ISSN: 1307-9581.

Gur, C. Kocak, N., Demircan, A., Baç Uslu, B., Sirin, N. \& Safak, M. (2015). Okulöncesi eğitim kurumlarına devam eden 48-60 ay çocukların sosyal yetkinlik ve davranış değerlendirme durumlarının incelenmesi.[The study of 48-60 month-old preschool children's social competence and behaviour evaluation conditions] Education and Science, 40 (180), 13-23. Doi: 10.15390/EB.2015.4563

Halle, T. G., \& Darling-Churchill, K. E. (2016). Review of measures of social and emotional development. Journal of Applied Developmental Psychology, 45, 8-18. https://doi.org/10.1016/j.appdev.2016.02.003

Halpenny, A. M., Nixon, E. \& Watson, D. (2010). Summary report on parents' and children's perspectives on parenting styles and discipline in Ireland. Reports. 13. https://arrow.dit.ie/aaschsslrep/13

Hong, J. S., Huang, H., Golden, M., Patton, D. U., \& Washington, T. (2014). Are community violence-exposed youth at risk of engaging in delinquent behavior? A review and 
implications for residential treatment research and practice. Residential Treatment for Children \& Youth, 31(4), 266-283, https://doi.org/10.1080/0886571X.2014.958343

Humphrey, J. H. (2003). Child Development Through Sports. U.S.A. The Haworth.

Hygen, B. W., Belsky, J., Stenseng, F., Skalicka, V., Kvande, M. N., Zahl-Thanem, T. \& Wichstrom, L. (2019). Time spent gaming and social competence in children: Reciprocal effects across childhood. Child Development, 91(13),1-15. https://onlinelibrary.wiley.com/doi/epdf/10.1111/cdev.13243

Joseph, G. E. \& Strain, P. S. (2003). Comprehensive evidence-based social-emotional curricula for young children: An analysis of efficacious adoption potential. Topics in Early Childhood Special Education, 23(2), 62-73. https://doi.org/10.1177/02711214030230020201

Kennedy, A. S. (2018). Promoting the social competence of each and every child in inclusive early childhood classrooms, in Early childhood Education (pp: 1-13). DOI: 10.5772/intechopen.80858

Kilic, S., Kumandas, H., \& Calik Var, E. (2016). Predictors of preschoolers' social competence: Parental discipline practices. International Journal of Human Sciences, 13(1), 466-478. https://doi.org/10.14687/ijhs.v13i1.3476

Kocyigit, S., Yilmaz, E. \& Sezer, T. (2015). The investigating of the relationship among social competence, emotion regulation skills and play skills of 60-72 months old children, HAYEF Journal of Education, 12(1), 209-218. http://dergipark.org.tr/iuhayefd/issue/8802/110041

Kordi, A., \& Baharudin, R. B. (2010). Parenting attitude and style and its effect on children's school achievements. International Journal of Psychological Studies, 2(2), 217-222. Doi: $10.5539 / \mathrm{ijps} . \mathrm{v} 2 \mathrm{n} 2 \mathrm{p} 217$

Ladd, G.W. (2000). The fourth relationships as risks and resources following children's transition to school. American Educational Research Association Division E Newsletter, 19(1), 79-11.

LaFreniere, P., Masataka, N., Butovskaya, M., Chen, Q., Auxiliadora Dessen, M., Atwanger, K., Schreiner, S., Montirosso, R. \& Frigerio, A. (2002). Cross-cultural analysis of social competence and behavior problems in preschoolers. Early Education and Development, 13(2), 201-220. https://doi.org/10.1207/s15566935eed1302_6

Lim, S. M., Rodger, S. \& Brown, T. (2010). Validation of Child Behavior Rating Scale in Singapore (Part 1): Rasch Analysis. Hong Kong Journal of Occupational Therapy, 20(2), 52-62. https://doi.org/10.1016/S1569-18611170004-3

Liman, B. (2020). Examining the social competence and behavior of 60-72 month-old children according to some variables. Dicle University Journal of Ziya Gökalp Education Faculty, 37, 8-19.Doi:http://dx.doi.org/10.14582/DUZGEF.2020.136.

McWayne, C., \& Cheung, K. (2009). A picture of strength: Preschool competencies mediate the effects of early behavior problems on later academic and social adjustment for Head Start children. Journal of Applied Developmental Psychology, 30, 273-285. http://dx.doi.org/10.1016/j.appdev.2008.12.014

Mei-Ju, C., Chen-Hsin, Y. \& Pin-Chen, H. (2014). The beauty of character education on preschool children's parent-child relationship. Procedia-Social and Behavioral Sciences, 143, 527-533. http://creativecommons.org/licenses/by-nc-nd/3.0/

Mendez, J., Fantuzzo, J. \& Cicchetti, D. (2002). Profiles of social competence among lowincome African American preschool children. Child Development, 73(4), 1085-1100. Retrieved from http://www.jstor.org/stable/3696272

Morgan, J. K., Izard, C. E. \& Hyde, C. (2013). Emotional reactivity and regulation in Head Start Children: Links to ecologically valid behaviors and internalizing problems. Social Development, 3(2), 250-266. Doi: 10.1111/sode.12049. 
Ozkan, H. K. \& Aksoy, A. B. (2017). An investigation of maternal emotion socialization behaviors, children's self-perceptions and social problem - solving skills. Eurasian Journal of Educational Research, 67, 125-139.

Ozyurek, A., Begde, Z. \& Yavuz, N. F. (2014). The relationship between pre-school children's social skills and interactions with the adults in the neighborhood, Social Sciences Research Journal, 16(2), 115-134. Doi:10.5578/JSS.8243

Parker, J. G, Rubin, K. H, Erath, S. A, Wojslawowiczx, J. C \& Buskirk, A. A. (2006). Peer relationships, child development, and adjustment: A developmental psychopathology perspective. In D. Cicchetti \& D. J. Cohen (Eds.), Developmental Psychopathology. 1, (pp. 419-493). New York: Wiley.

Patterson, G., \& Sanson, A. (1999). The association of behavioural adjustment to temperament, parenting and family characteristics among 5-year old children. Social Development, 8(3), 293-309. Doi: 10.1111/1467-9507.00097

Prinstein, M. J. ve La Greca, A. M. (2004). Childhood peer rejection and 1054 FRASER ET AL. Aggression as predictors of adolescent girls' externalizing and health risk behaviors: A 6-year longitudinal study. Journal of Consulting and Clinical Psychology, 72, 103-112.

Scaramella L.V. \& Leve L. D. (2004). Clarifying parent-child reciprocities during early childhood: The early childhood coercion model. Clinical Child and Family Psychology Review, 7(2), 89-107. https://doi.org/10.1023/B:CCFP.0000030287.13160.a3

Simkiss, D.E., MacCallum, F., Fan, E.Y., Oates, J. M., Kimani, P.K., \& Stewart-Brown, S. (2013). Validation of the Mothers Object Relations Scales in 2-4 year old children and comparison with the Child-Parent Relationship Scale. Healthand Quality of Life Outcomes, 11 (1), 11-49. Doi: 10.1186/1477-7525

Schmidt, M.E., Demulder, E. K., \& Denham, S. A. (2002). Kindergarten social-emotional competence: Developmental predictors and psychosocial implications. Early Child Development and Care, 172, 451-462. Doi: 10.1080/03004430214550

Smith, S. M., Simon, J., \& Bramlett, R. K. (2009). Effects of positive peer reporting (PPR) on social acceptance and negative behaviors among peer-rejected preschool children. Journal of Applied School Psychology, 25(4), 323-341. http://dx.doi.org/10.1080/15377900802595359

Sirois, M. S., Bernier, A., Lemelin, J. P. (2019). Child temperamental anger, mother-child interactions and socio-emotional functioning at school entry. Early Childhood Research Quarterly, 47, 30-38. https://doi.org/10.1016/j.ecresq.2018.10.005

Surmeli, E. S. (2018). The study of 5-6 year old children's social competence behaviors. Unpublished Master Thesis. Istanbul Maltepe University, Institute of Social Sciences, Istanbul.

Thomson, R. N., \& Carlson, J. S. (2017). A pilot study of a self-administered parent training intervention for building preschoolers' social-emotional competence. Early Childhood Education Journal, 45(3), 419-426. https://doi.org/10.1007/s10643-016-0798-6

Webster-Stratton, C., \& Taylor, T. (2001). Nipping early risk factors in the bud: Preventing substance abuse, delinquency, and violence in adolescence through interventions targeted at young children (0 to 8 Years). Prevention Science, 2(3), 165-192. http://dx.doi.org/10.1023/A:1011510923900

Wood, J. J., Emmerson, N. A., \& Cowan, P. A. (2004). Is early attachment security carried forward into relationships with preschool peers? British Journal of Developmental Psychology, 22(2), 245-253. http://dx.doi.org/10.1348/026151004323044591 
Ural, O., Güven, G., Sezer, T., Azkeskin, K. E., \& Y1lmaz, E. (2015). Investigation of the relationship between the attachment ways of pre-school children and their social competency and emotion regulation skills, Hacettepe University Faculty of Health Sciences Journal, 1(2), 589-598.

Uygun, N., \& Kozikoğlu, İ. (2019). The study of social competence behaviors of children attending pre-school education institutions. Ege Journal of Education, 20(1), 305-321. Doi: 10.12984/egeefd.526276.

Uysal, H., \& Akman, B. (2016). The Adaptation of Social Competence and Behavioral Evaluation Scale into Turkish. Amasya Education Journal, 5(2), 419-446. Doi:10.17539/aej.93567

Vahedi, S., Farrokhi, F., \& Farajian, F. (2012). Social competence and behavior problems in preschool children. Iran Journal Psychiatry, 7, 126-134.

Varley D., Wright B, Cooper C., Marshall, D., Biggs, K., Ali, S., Chater, T., Coates, E., Gilbody, S., Cuesta, g. G., Kingsley, E., Couteur, A. L., McKelvey, A., Stephard, N \& Teare, D. (2019). Investigating social competence and isolation in children with autism taking part in LEGO-based therapy clubs in school environments (ISOCIALISE): Study protocol, BMJ Open, 9:e030471. Doi:10.1136/bmjopen-2019030471 https://bmjopen.bmj.com/content/9/5/e030471

Yarali, K. T., \& Ozkan, H. K. (2016). Examination of relation between children's (60- 72 months) social problem-solving skills with social competence and behavioral status. Turkish Journal of Social Research, August, 345-361. https://trdizin.gov.tr/publication/show/pdf/paper/TWpFeE5EVXdNQT09

Yasar-Ekici, F. (2014). Investigating the relationship between family characteristics and problem behaviours of the children that attending pre-school education, The Journal of Academic Science, 2(2),70-108.

Yavuz, H. M., Selcuk, B. \& Korkmaz, B. (2017). Social competence in children with autism, International Journal of Developmental Disabilities, 65(1), 10-19. https://doi.org/10.1080/20473869.2017.1346224

Yoleri, S. (2014). The effects of age, gender, and temperament traits on school adjustment for preschool children, e-International Journal of Educational Research, 5(2), 54-66. https://doi.org/10.19160/e-ijer.55208

Zhang, X. (2011). Parent-child and teacher-child relationships in Chinese preschoolers: The moderating role of preschool experiences and the mediating role of social competence. Early Childhood Research Quarterly, 26 (2), 192-204.

Zhang, X. (2013). Bidirectional longitudinal relations between father-child relationships and Chinese children's social competence during early childhood. Early Childhood Research Quarterly, 28, 83-93. 